\title{
Perspective Piece \\ Food Security and COVID-19 in Africa: Implications and Recommendations
}

\author{
Esraa Mahadi Ali Mohamed, ${ }^{1,2}$ Samar Mohammed Alhaj Abdallah, ${ }^{3}$ Attaullah Ahmadi, ${ }^{4 \star}$ and Don Eliseo Lucero-Prisno III ${ }^{5,6}$ \\ ${ }^{1}$ Department of Health Financing and Economics, Directorate General of Health Planning \& Policy, Federal Ministry of Health, Khartoum, Sudan; \\ ${ }^{2}$ Department of Health Economics, Alsudani Centre for Training in Heal Economics ACTHE, Khartoum, Sudan; ${ }^{3}$ School of Medicine, Ahfad \\ University for Women, Khartoum, Sudan; ${ }^{4}$ Medical Research Center, Kateb University, Kabul, Afghanistan; ${ }^{5}$ Department of Global Health and \\ Development, London School of Hygiene and Tropical Medicine, London, United Kingdom; ${ }^{6}$ Faculty of Management and Development Studies,
} University of the Philippines (Open University), Los Baños, Philippines

\begin{abstract}
Before the COVID-19 pandemic ravaged Africa, a large percentage of Africans were already affected by poverty and food insecurity. The pandemic wreaked havoc on their already unfavorable situation. The direct and indirect impacts of COVID-19 included but not limited to illness and deaths of food systems' workers, interruption of food supply chains, unemployment, depreciation of currency value, and disruption of social protection programs. COVID-19 will lead to further economic fallout. Thus, the situation needs careful observation and timely intervention to safeguard the vulnerable African communities. Although Africa has sought ways to lessen the dire impact of the pandemic on food security, short-term solutions should include and enhance social and economic relief initiatives such as monetary intervention and social safety net. Considering a balance between health benefits of COVID-19 restrictions and their economic implications, the African countries, at the regional level, must preserve open and efficient social protection programs and crossborder supply and distribution networks for agricultural inputs. Africa's medium- and long-term strategies for improving food security should include improving and diversifying its agricultural productivity and production of key food commodities. This will reduce Africa's dependence on importation of these key commodities, and will help the continent address underlying economic vulnerabilities and better manage food, pandemic, and/or health-related crises affecting food security in the long term.
\end{abstract}

\section{INTRODUCTION}

Food security is defined as a condition in which all the people, at all times, have physical and economical access to adequate, safe, and nutritious food, meeting their nutritional requirements and their food preferences for an active and a balanced life. ${ }^{1}$ However, despite fundamental efforts and accomplishments in the battle against poverty in recent decades, many countries in Africa have been suffering from economic recession, and many Africans are profoundly affected by the dramatic fallout of livelihoods and income. There is a large number of people in Africa who live under the poverty line and are vulnerable to food insecurity. ${ }^{2}$ Although the poverty rate in Africa has declined from $54 \%$ in 1990 to $41 \%$ in 2015, the number of poor people has increased from 278 million to 413 million during the same period because of high population growth. ${ }^{3}$

The latest figures in Africa show that 73 million people suffer from acute food insecurity. ${ }^{4}$ From 2016 to 2018 , Africa imported around $85 \%$ of its food from outside the continent, making an annual food bill of $\$ 35$ billion, which is projected to hit $\$ 110$ billion by 2025 . This heavy dependence on world markets is hazardous for food security, particularly in times of prolonged crisis. ${ }^{4}$ African regions, especially the Sahel and southern Africa, have been harshly affected by climate change and drought since last year. ${ }^{4}$ The unprecedented locust outbreak in the Horn of Africa has put an additional pressure on regional food systems. Conflict hampers people's access to food as farmers abandon their farms and do not bring their products to markets to avoid risking their lives. ${ }^{5}$ Hence, given the prevalence of conflict and political instability, the region is at great risk of food insecurity. 4,6

*Address correspondence to Attaullah Ahmadi, Medical Research Center, Kateb University, Darulaman Rd., Kabul 1004, Afghanistan. E-mail: attaullah.ahmadi@kateb.edu.af
In light of the COVID-19 pandemic, the greatest public health threat of our time, ${ }^{7}$ not only the health of African people but also their socioeconomic status and food security have greatly been affected. ${ }^{8}$ The pandemic has led to various government-led restrictions and interventions ${ }^{9,10}$ to curb the spread of the virus on the continent wreaking havoc on the continent's food supply, and compounding the already bleak picture of food security in Africa. ${ }^{11}$ This article aims to highlight Africa's efforts to mitigate the impact of COVID-19, its implications to food security in Africa, and the recommendations to boost food security amid and after the pandemic in the continent.

\section{EFFORTS}

Africa has sought ways to lessen the dire impact on food security brought about by the pandemic. Led by the lessons learned from previous health crises, including the Ebola outbreak in 2014-2015 and the food crisis in 2008-2009, the African Development Bank responded to the epidemics by bringing together a robust public and private sector package, Feed Africa Response to COVID-19 (FAREC). ${ }^{12}$ Feed Africa Response to COVID-19 promotes the growth of resilience, sustainability, and self-sufficiency in food production and distribution by the African governments, farmers, and the private sector, particularly small and medium-sized enterprises. It also responds to minimize COVID-19-related disturbances to the value chain of agriculture. As of mid-June 2020, FAREC assisted 23 African countries in finding capital in current bank-financed farm loans to fund farm inputs, building "green corridors" for a free flow of food, and stabilize food prices, via the targeted release of grain and the replenishment of food stocks. ${ }^{12}$ Moreover, some African countries also provided stimulus packages in the forms of cash or food aimed at assisting those citizens who lost their jobs and income because of COVID-19 restrictions. ${ }^{11,13}$ 


\section{IMPLICATIONS OF COVID-19}

The measures taken to contain COVID-19 spread have had significant implications for food systems, nutrition, and food security in Africa. Many dynamics threatened food security during the pandemic. The disruption of food supply chains during the lockdown period affected food availability, pricing, and quality. The World Bank estimates that millions of people will experience extreme poverty as the lockdown policies, closure of borders and restrictions on transportations resulted in the disruption of the food supply chains and the slowdown of the economic activities. ${ }^{4,14}$ The restrictions on exportations and importations of essential food items such as wheat and rice have made many African countries vulnerable because of their dependence on importation of these items. Moreover, the illnesses of food systems workers also played a major role in the disruption of supply chains. Many people lost their jobs during the lockdown period, especially those who work in informal sectors and procure their income on a daily basis. ${ }^{4,14}$

Agriculture is one of the most significant economic sectors in Africa, which makes up $23 \%$ of the continent's Gross Domestic Product (GDP). Nearly $60 \%$ of the economically active populations in sub-Saharan Africa are employed in this area. ${ }^{6}$ In rural areas of Africa, agriculture is considered as the main source of nutrition and income. However, the disruption of transportation and livelihoods due to the restrictions have made it difficult for farmers to sell their products and make them available for the population, and they could not gain access to veterinary services either. ${ }^{15}$ It is expected that the agri-food sector can be spared and expanded, as the collapse in export earnings and the loss of food import capacity push domestic production upward. Lower labor demand in the urban service sectors will drive workers back to farming, leading to higher domestic food production. However, workers' income would decrease with more workers joined in the sector while their products are not sold. ${ }^{16}$ Furthermore, many people in Africa, especially poor families, depend on social protection programs that were hampered during the pandemic. For instance, schoolchildren lost their meals because of the closure of schools caused by the disruption of social protection programs. ${ }^{15}$ With COVID-19 now expanding to the poorest areas of Africa and the economic fallout rising, even more people are at great risk of becoming poor and food-insecure. The International Labor Organization estimates that 200 million employees will be thrown into unemployment across the globe, and Africans are not spared from this issue. ${ }^{12}$

\section{RECOMMENDATIONS}

The COVID-19 pandemic will lead to further economic fallout. Thus, the situation needs careful observation and timely intervention to safeguard the vulnerable African communities from food insecurity. As COVID-19 expands in Africa, shortterm solutions should include social and economic relief initiatives including monetary intervention and social safety net to mitigate and avert a drastic rise in poverty and hunger in the continent. The COVID-19 pandemic strongly illustrated the degree of intercountry interconnectedness and the importance of retaining trading ties, ensuring minimum food chain disturbances. Hence, considering a balance between health benefits of COVID-19 restrictions and their economic implications, the African governments, at the regional level, must preserve open and efficient social protection programs and cross-border supply and distribution networks for agricultural inputs. This will allow the flourishing of robust value chains that connect domestic and regional markets. ${ }^{16}$ The movement of goods, including food, and associated vital services (i.e., transportation) should be assured in the continent while relaxing restriction policies. ${ }^{4}$

The COVID-19 pandemic also highlights the need for medium- and long-term strategies to further build Africa's food security capacity. Africa can achieve this goal by improving its agricultural productivity and production of key food commodities. This will reduce Africa's dependence on importation of key commodities, which has been one of the main factors for increasing their vulnerability to food insecurity due to high prevalence of poverty in the continent. This strategy will also help the continent address underlying economic vulnerabilities and better manage food, pandemic, and/or health-related crises affecting food security in the long term. ${ }^{2,11}$

In Africa, food security is likely to benefit from the effective implementation of the African Continental Free Trade Area (AFCFTA). African Continental Free Trade Area ensures the creation of jobs and income to battle poverty and food insecurity through greater economic diversification (value addition and intraAfrican trade). ${ }^{4}$ Hence, diversifying Africa's commodity base and adding value to that can be achieved if significant increase in agricultural labor productivity and full implementation of AFCFTA is ensured. ${ }^{4}$ The short-, medium-, and long-term responses of the African governments need to feed Africa's rising population, which is 1.2 billion today and is expected to increase in the next decades. In these strategies, a special focus should be used on disadvantaged communities to benefit from nutrition services. ${ }^{12}$

\section{CONCLUSION}

Food insecurity was rampant in Africa even before the COVID-19 pandemic ravaged the continent. COVID-19 restrictions jeopardized not only the health but also food security of Africans. Although Africa has sought ways to lessen the dire impact of the pandemic on food security, the need for more interventions to boost African food systems has been indicated by these stresses. Short-term solutions should include social and economic relief initiatives such as monetary intervention and social safety net. While lifting COVID-19 restrictions, the African countries, at the regional level, must preserve open and efficient social protection programs and cross-border supply and distribution networks for agricultural inputs. Africa's medium- and long-term strategies for improving food security should include improving and diversifying its agricultural productivity and production of key food commodities to reduce their dependence on importation of key commodities, and to address the continent's underlying economic vulnerabilities.

Received December 15, 2020. Accepted for publication February 28, 2021.

Published online March 8, 2021.

Acknowledgment: The American Society of Tropical Medicine and Hygiene has waived the Open Access fee for this article due to the ongoing COVID-19 pandemic and has assisted with publication expenses.

Authors' addresses: Esraa Mahadi Ali Mohamed, Department of Health Financing and Economics, Directorate General of Health 
Planning \& Policy, Federal Ministry of Health, Khartoum, Sudan, and Department of Health Economics, Alsudani Centre for Training in Heal Economics ACTHE, Khartoum, Sudan, E-mail: esraamahadi@ gmail.com. Samar Mohammed Alhaj Abdallah, School of Medicine, Ahfad University for Women, Khartoum, Sudan, E-mail: summerdrought62@gmail.com. Attaullah Ahmadi, Medical Research Center, Kateb University, Kabul, Afghanistan. E-mail: attaullah.ahmadi@ kateb.edu.af. Don Eliseo Lucero-Prisno III, Department of Global Health and Development, London School of Hygiene and Tropical Medicine, London, United Kingdom, and International Health Program, Faculty of Management and Development Studies, University of the Philippines Open University Los Baños, Laguna, Philippines. E-mail: don-eliseo. lucero-prisno@lshtm.ac.uk.

This is an open-access article distributed under the terms of the Creative Commons Attribution (CC-BY) License, which permits unrestricted use, distribution, and reproduction in any medium, provided the original author and source are credited.

\section{REFERENCES}

1. FAO, 2008. An Introduction to the Basic Concepts of Food Security. Available at: http://www.fao.org/3/a-al936e.pdf. Accessed December 7, 2020.

2. Juma CA, Mushabaa NK, Abdu Salam F, Ahmadi A, Lucero-Prisno DE, III, 2020. COVID-19: the current situation in the Democratic Republic of Congo. Am J Trop Med Hyg 103: 2168-2170.

3. The World Bank, 2019. Accelerating Poverty Reduction in Africa: In Five Charts. Available at: Accelerating Poverty Reduction in Africa: In Five Charts (worldbank.org). Accessed December 10, 2020.

4. Akiwumi P, 2020. COVID-19: A threat to food security in Africa. Available at: https://unctad.org/news/covid-19-threat-foodsecurity-africa. Accessed December 8, 2020.

5. Dado MK, 2020. Understanding African's Food Security Challenges. International Academy of Social Sciences. Available at: https://www.intechopen.com/books/food-security-in-africa/ understanding-africa-s-food-security-challenges. Accessed February 16, 2021. doi: 10.5772/intechopen.91773.

6. Pais G, Jayaram K, Wamelen AV, 2020. Safeguarding Africa's Food Systems Through and Beyond the Crisis. Available at: https://www.mckinsey.com/featured-insights/middle-east-andafrica/safeguarding-africas-food-systems-through-and-beyondthe-crisis. Accessed December 10, 2020.

7. Dzushupov K, Lucero-Prisno DE, III, Vishnyakov D, Lin X, Ahmadi A, 2020. COVID-19 in Kyrgyzstan: navigating a way out. J Glob Health 11: 03020.

8. Dinyo DGA, Ahmadi A, Okereke M, Essar MY, Lucero-Prisno DE, 2020. South Sudan: a young country's fight against COVID-19. Pan Afr Med J 37: 49.

9. Ahmadi A, Essar MY, Lin X, Adebisi YA, Lucero-Prisno DE, 2020. Polio in Afghanistan: the current situation amid COVID-19. AmJ Trop Med Hyg 103: 1367-1369.

10. Lucero-Prisno DE et al., 2020. Drug shortage crisis in Sudan in times of COVID-19. Public Health Pract. doi: 10.1016/j.puhip.2020. 100060.

11. Lucero-Prisno DE, 3rd, Adebisi YA, Lin X, 2020. Current efforts and challenges facing responses to $2019-n C o V$ in Africa. Glob Health Res Pol 5: 21.

12. Blanke J, 2020. Economic Impact of COVID-19: Protecting Africa's Food Systems from Farm to Fork. Available at: https:// www.brookings.edu/blog/africa-in-focus/2020/06/19/economicimpact-of-covid-19-protecting-africas-food-systems-from-farmto-fork. Accessed December 10, 2020.

13. Amesho JN, Ahmadi A, Lucero-Prisno DE, 2020. The calculated responses against COVID-19 in Namibia. Pan Afr Med J 37: 25.

14. HLPE, 2020. Impacts of COVID-19 on Food Security and Nutrition: Developing Effective Policy Responses to Address the Hunger and Malnutrition Pandemic. Available at: www.fao.org/ 3/cb1000en/cb1000en.pdf. Accessed December 10, 2020.

15. Arndt C, Davies R, Gabriel S, Harris L, Makrelov K, Robinson S, Levy S, Simbanegavi W, van Seventer D, Anderson L, 2020. COVID-19 lockdowns, income distribution, and food security: an analysis for South Africa. Glob Food Sec 26: 100410.

16. Laborde D, Martin W, Vos R, 2020. Poverty and Food Insecurity Could Grow Dramatically as COVID-19 Spreads. Washington, DC: International Food Policy Research Institute (IFPRI). Available at: https://www.ifpri.org/blog/poverty-and-food-insecuritycould-grow-dramatically-covid-19-spreads. Accessed December 10, 2020. 